\title{
INTEGRATED ANALYSIS FOR GENOTYPIC ADAPTATION IN RICE
}

S. DAS, R.C. MISRA, S.R. DAS, M.C. PATTNAIK and S.K. SINHA

Department of Plant Breeding and Genetics, College of Agriculture, Orissa University of Agriculture and

Technology, Bhubaneswar, Orissa, India

Corresponding author: swarnalata1967@ rediffmail.com

(Received 4 February, 2010; accepted 16 December, 2010)

\begin{abstract}
Development of varieties with high yield potential coupled with wide adaptability is an important plant breeding objective. The presence of genotype by environment $(\mathrm{GxE})$ interaction plays a crucial role in determining the performance of genetic materials, tested at different locations and in different years. This study was undertaken to assess yield performance, stability and adaptability of thirty-six rice genotypes of three different maturity groups evaluated over 12 environments. There were highly significant $(\mathrm{P}<0.05)$ genotype-environment interaction in three different maturity groups. The AMMI analysis of variance in the maturity groups also showed significant genotype,

location and $\mathrm{G}^{\prime} \mathrm{L}$. Stability in yield performance was predicted using nine stability parameters $\left(b, S_{d}^{2}, C V, S F, R_{1}\right.$, $\mathrm{R}_{2}, \mathrm{~W}, \mathrm{~S} 1$ and $\mathrm{ASV}$ ). The rank correlation coefficient among nine parameters indicated that the stability parameters were dissimilar in for all the maturity groups. Stability index (STI) computed by integrating all the nine stability parameters indicated that genotypes Lalat and OR 2006-12 of mid-early group, genotypes OR 1912-25, OR 231012 and MTU 1001 of mid-late group, and genotypes OR 1898-3-16, OR 1901-14-32, OR 2109-2, OR 2001-1, Mahanadi and Jagabandhu of late group yielded higher consistently over the 3 years in the different agroclimatic zones.
\end{abstract}

Key Words: Adaptation, AMMI stability value, stability index

\section{RÉSUMÉ}

Le développement de variétés à potentiel élevé de rendement couplé à une large adaptabilité est un objectif important de l'amelioration des plantes. La présence de génotype par interaction avec l'environnement (GxE) joue un rôle crucial dans la détermination des performances de matériels génétiques testés dans différentes localisations et dans des années différentes influençant le processus de sélection. L'étude était entreprise pour évaluer la performance en rendement, la stabilité et l'adaptabilité de trente six génotypes de riz de trois groupes de maturité différente évaluées sur 12 environnements. L'interaction génotype-environnement était significativement élevé $(\mathrm{P}<0.05)$ dans trois groupes de maturité différente. L'analyse AMM de la variance dans les groupes de maturité avait aussi montré un effet significatif du genotype, localisation et G'L. La stabilité en performance de rendement était prédite

utilisant neuf paramètres de stabilité ( $b, \mathrm{~S}_{\mathrm{d}}^{2}, \mathrm{CV}, \mathrm{SF}, \mathrm{R}_{1}, \mathrm{R}_{2}, \mathrm{~W}, \mathrm{~S} 1$ and $\mathrm{ASV}$ ). L'étude du niveau de coéfficient de corrélation parmi les neuf paramètres a indiqué que les paramètres de stabilité n'étaient pas les mêmes dans leurs degré de corrélation pour tous les groupes de maturité. L'index de stabilité (STI) calculé en intégrant tous les neuf paramètres de stabilité a indiqué que les génotypes Lalat et OR 2006-12 du mi-premier groupe, les génotypes OR 1912-25, OR 2310-12 et MTU 1001 du mi-dernier groupe et les génotypes OR 1898-3-16, OR 1901-14-32, OR 2109-2, OR 2001-1, Mahanadi et Jagabandhu du dernier groupe ont produit considérablement de rendements très élevés au cours des 3 ans dans différentes zones agroclimatiques.

Mots Cles: Adaptation, valeur de stabilité AMMI, index de stabilité 


\section{INTRODUCTION}

Development of varieties with high yield potential coupled with wide adaptability is an important plant breeding objective. The presence of genotype by environment ( $\mathrm{GxE}$ ) interaction plays a crucial role in determining the performance of genetic materials, tested at different locations and in different years, influencing the selection process (Becker and Leon, 1988; Purchase et al., 2000). Multilocation trials provide useful information on genotypic adaptation and stability (Crossa, 1990). The GxE interaction estimates help breeders to decide the breeding strategy, to breed for specific or general adaptation, which depends on stability in yield performance under a limited or wide range of environmental conditions (Romagosa and Fox, 1993).

Plant breeders generally agree on the importance of high yield stability, but disagree with the different methods used for stability analysis (Becker and Leon, 1988). Therefore, several biometrical methods including univariate and multivariate ones have been developed to assess stability (Akcura et al., 2005). Among the univariate approaches, the linear regression model of Eberhart and Russell (1966) is most widely adopted by the breeders (Chowdhury et al., 2002; Bose et al., 2004; Francis et al., 2005; Nanita Devi et al., 2006; Das et al., 2008) as it is mathematically simple. But this model could not determine which genotype is superior, because the genotype's response to environments is intrinsically multivariate and regression tries to transform it into a univariate problem.

The use of stability analysis other than analysis of variance (ANOVA) may also help in prediction of adaptability of genotypes. Wricke's ecovalence is an alternative method that is used by breeders to determine stability of genotypes based on GXE interaction effects (Mahapatra, 1993; Chandrasari et al., 2002; Das et al., 2008). It indicates the contribution of each genotype to the GXE interaction. When exposed to different environments, the responsive genotypes are not necessarily unstable, rather more desirable if there is consistency in yield as measured by coefficient of variation (CV) (Francis and Kannenberg, 1978).

Mahapatra and Das (1998) and Chandrasari et al. (2002) used CV to predict adaptability in rice. Among the multivariate approaches AMMI model is widely used (Asenjo et al., 2003; Mahalingam et al., 2006 and Das et al.,,2008). In AMMI, the response patterns of the genotypes to environmental change can be extrapolated to a much wider range of environments. AMMI stability value (ASV) statistic was developed by Purchase (1997) to quantify and rank the genotypes on the basis of their yield stability. ASV is based on AMMI model's PCA 1 and PCA 2 scores for each genotype. It is in effect the distance from the co-ordinate point to the origin in a two dimensional scatter gram of PCA 1 score against PCA 2score. Many methods are available for the analysis of GxE interaction and adaptability (Lin et al., 1986; Hohls, 1995). But the prediction of adaptability of the genotypes may vary depending on the biometrical methods followed, i.e. a genotype found to be stable in one biometrical method may not be stable in other. Therefore, the integration of several biometrical approaches may give a better result than the use of a single method in predicting the adaptability and stability in yield performance. The aim of the present investigation was to analyse genotypic adaptation in rice by integrating both univariate and multivariate methods of stability analysis.

\section{MATERIALS AND METHODS}

Thirty six rice genotypes ( Table 1) of 3 different maturity groups - 11 of mid-early (115-125), 13 mid-late (126-140) and 12 of late (145$165)$ group were evaluated in three multilocation trials each at 4 different agroclimatic zones of Orissa (Bhubaneswar, Chiplima, Jeypore and Ranital; Table 2), India over 3 years, during 2004-2006 in kharif (wet) season using a randomised block design with three replications. For all trials, nursery sowing was done during last week of June to the first week of July. Twenty-five to thirty days old seedlings were transplanted with $20 \mathrm{~cm} \times 15 \mathrm{~cm}$ spacing and 2 seedlings per hill. In each trial, the plot size 
TABLE 1. Parentage of mid-early, mid-late and late rice genotypes

Name of genotype Parentage

\section{Mid-early (115-125 days)}
1. OR $1739-47$
2. OR $1916-19$
3. OR 1929-4
4. OR $1976-11$
5. OR 2006-12
6. OR 2168-1
7. OR 2172-7
8. OR $2200-5$
9. Konark
10. Lalat
11. Bhoi

Sankar/IR 72

Lalat/Ratna

OR 929-3-2/RP 2423-108-97

TRC 87-125//IR 49517/Prana

Sarathi/IR 36

IR 36/UPRI 3

IR 64///IR 72//Jagannath/NCJ 10

RP 2423-108-97/ORS 199-2

Lalat/OR 135-3-4

Obs 677/IR 2071// Vikram/W1263

Gouri/RP 825-45-1-3

\section{Mid-late (126-140 days)}
1. OR 1681-11
2. OR 1912-25
3. OR $1914-8$
4. OR 1964-8
5. OR $1967-15$
6. OR $2156-15$
7. OR $2310-12$
8. Pratikshya
9. Gouri
10. Surendra
11. Gajapati
12. Kharavela
13. MTU 1001

\section{Late (145-165 days)}

$\begin{array}{lll}\text { 1. } & \text { OR 1885-16-34 } & \text { IR 72/Kanchan } \\ \text { 2. } & \text { OR 1898-2-15 } & \text { Mahalaxmi/OR 633-7 } \\ \text { 3. } & \text { OR 1898-3-16 } & \text { Mahalaxmi/OR 633-7 } \\ \text { 4. } & \text { OR 1901-14-32 } & \text { Manika//R 72 } \\ \text { 5. } & \text { OR 2001-1 } & \text { RP 1125-606-32/Rambha } \\ \text { 6. } & \text { OR 2109-2 } & \text { Indravati//IR 72/Salivahan } \\ \text { 7. } & \text { OR 2119-13 } & \text { Manika/Manasarovar } \\ \text { 8. } & \text { Savitri } & \text { Pankaj/Jagannath } \\ \text { 9. Salivahan } & \text { RP 5-32/Pankaj } \\ \text { 10. Mahanadi } & \text { IR 19661/Savitri } \\ \text { 11. Kanchan } & \text { Jajati/Mahsuri } \\ \text { 12. Jagabandhu } & \text { Savitri//R 4819-77-3-2//IR 27301- } \\ & \text { 154-3 }\end{array}$

was $2 \mathrm{~m} \times 3 \mathrm{~m}$ containing 10 rows of $3 \mathrm{~m}$ length each.

The yield data of the 12 environments ( 4 locations x 3 years) were subjected to stability analysis following univariate methods like regression co-efficient (b) and deviation from regression $\left(\mathrm{S}_{\mathrm{d}}^{2}\right)$ of Eberhart and Russell (1966), co-efficient of variation (CV) of Francis and Kannenberg (1978), two range parameters $\left(\mathrm{R}_{1}\right.$ and $\mathrm{R}_{2}$ ) of Langer et al. (1979), stability factor (SF) proposed by Lewis (1954), ecovalence (W) of Wricke (1962), mean absolute rank difference (S1) of Nassar and Huhn (1987) and the multivariate method AMMI(Additive main effects and multiplicative interaction) stability value (ASV) of Purchase (1997). The models are described below.

Linear regression model. Adaptability and stability of performance of genotypes for grain yield were analysed, using the linear regression model of Eberhart and Russell (1966) as follows:

$\mathrm{Y}_{-_{\mathrm{ij}}}=\mathbf{a}_{\mathrm{i}}+\mathrm{b}_{\mathrm{i}} \mathrm{I}_{\mathrm{j}}+\mathrm{d}_{\mathrm{ij}}, \quad(\mathrm{i}=1, \mathrm{~g} ; \mathrm{j}=1, \mathrm{n})$,

where:

$\mathrm{Y}_{\mathrm{ij}}=$ mean of $\mathrm{i}^{\text {th }}$ genotype in $\mathrm{j}^{\text {th }}$ environment;

$I_{j}=$ environmental index of $j^{\text {th }}$ environment, i.e. $j^{\text {th }}$ environment mean (over all genotypes) minus the grand mean;

$\mathrm{a}_{\mathrm{i}}=$ mean of $\mathrm{i}^{\text {th }}$ genotype over all environments;

$b_{i}=$ regression coefficient which measures the response of $i^{\text {th }}$ genotype to the varying environments;

$\mathrm{d}_{\mathrm{ij}}=$ deviation from regression of $\mathrm{i}^{\text {th }}$ genotype at $\mathrm{j}^{\text {th }}$ environment, i.e., $\mathrm{d}_{\mathrm{ij}}=\mathrm{Y}_{\mathrm{ij}}-\hat{\mathrm{Y}}_{\mathrm{ij}}$.

The regression coefficient 'b' was estimated as:

$b_{i}=\frac{\sum_{j} Y_{i j} I_{j}}{\sum_{j} I_{j}^{2}}$ 
TABLE 2. Environmental variation of four experimental regions (Source: Agrometerology, OUAT, Bhubaneswar)

\begin{tabular}{lllcc}
\hline Different regions & Latitude & Longitude & Average rain fall $(\mathrm{mm})$ & Temperature $\left(^{\circ} \mathrm{C}\right)$ \\
\hline Bhubaneswar & $18^{0} 40^{\prime}-20^{0} 15^{\prime} \mathrm{N}$ & $83^{\circ} 48^{\prime}-87^{\circ} 40^{\prime} \mathrm{N}$ & 1340.0 & $11.5-39^{\circ} \mathrm{C}$ \\
Chiplima & $16^{0} 15^{\prime}-20^{\circ} 52^{\prime} \mathrm{N}$ & $82^{0} 13^{\prime}-85^{\circ} 15^{\prime} \mathrm{N}$ & 1180.0 & $12.0^{\circ}-40.0^{\circ} \mathrm{C}$ \\
Jeypore & $10^{0} 20^{\prime}-20^{0} 10^{\prime} \mathrm{N}$ & $81^{0} 50^{\prime}-83^{\circ} 20^{\prime} \mathrm{N}$ & 1347.1 & $7.5-39.1^{\circ} \mathrm{C}$ \\
Ranital & $22^{\circ} 40^{\prime}-23^{\circ} 48^{\prime} \mathrm{N}$ & $86^{0} 16^{\prime}-87^{\circ} 25^{\prime} \mathrm{N}$ & 1488.0 & $24.0^{\circ} 38.0^{\circ} \mathrm{C}$ \\
\hline
\end{tabular}

The stability parameter, measuring deviation from regression ( ) was estimated as follows:

$S_{\mathrm{di}}^{2}=\frac{\sum_{\mathrm{j}} \mathrm{d}_{\mathrm{ij}}^{2}}{\mathrm{n}-2}-\frac{\mathrm{S}_{\mathrm{e}}^{2}}{\mathrm{r}}$

where $\sum_{j} d_{i j}^{2}=\left[\sum_{j} Y_{i j}^{2}-\frac{Y_{i .}^{2}}{n}\right]-\frac{\left(\sum_{j} Y_{i j} . I_{j}\right)^{2}}{\sum_{j} I_{j}^{2}}$

$\mathrm{S}_{\mathrm{e}}^{2}=$ pooled error mean square;

$\mathrm{r} \quad=$ number of replications; and

$\mathrm{n}=$ number of environments.

Coefficient of variation (CV). Use of coefficient of variation as a stability parameter was proposed by Francis and Kannenberg (1978). The parameter was estimated as:

$$
\mathrm{CV}=\frac{\mathrm{SD}_{\mathrm{x}}}{\overline{\mathrm{X}}} \times 100
$$

where $\mathrm{SD}_{\mathrm{x}}$ is standard deviation of the means of a genotype over environments and is the mean of the genotype over all environments.

Range parameters. Two range parameters $\left(R_{1}\right.$ and $\mathrm{R}_{2}$ ) were estimated as follows, after Langer et al. (1979).

$\mathrm{R}_{1}=\overline{\mathrm{X}}_{\mathrm{H}}-\overline{\mathrm{X}}_{\mathrm{L}}$

$\mathrm{R}_{2}=\overline{\mathrm{X}}_{\mathrm{HE}}$ and $\overline{\mathrm{X}}_{\mathrm{LE}}$

where $\bar{X}_{H}$ and $\bar{X}_{L}$ are the highest and lowest mean yields of a genotype over the range of environments and $\bar{X}_{\mathrm{HE}}$ and $\bar{X}_{\mathrm{LE}}$ are mean yields of a genotype in the highest-yielding and lowest-yielding environments.
Stability factor. Stability factor (SF) of a genotype as proposed by Lewis (1954) was estimated as:

$\mathrm{SF}=\frac{\overline{\mathrm{X}}_{\mathrm{HE}}}{\overline{\mathrm{X}}_{\mathrm{LE}}}$

where $\bar{X}_{\mathrm{HE}}$ is mean of the genotype in the highest -yielding environment; and

$\overline{\mathrm{X}}$ is mean of the genotype in the lowest $\overline{\mathrm{X}}_{\mathrm{LE}}$ yielding environment.

Ecovalence (W). According to Wricke (1962) Ecovalence $\left(\mathrm{W}_{\mathrm{i}}\right)$ of a genotype was estimated as:

$W_{i}=\sum_{j}\left[Y_{i j}-\frac{Y_{i} \cdot}{n}-\frac{Y_{\cdot j}}{g}+\frac{Y . .}{g n}\right]^{2}$

where $\mathrm{Y}_{\mathrm{ij}}=$ mean of $\mathrm{i}^{\text {th }}$ genotype in $\mathrm{j}^{\text {th }}$ environment;

$\mathrm{Y}_{\mathrm{i}}$. $=$ total of $\mathrm{i}^{\text {th }}$ genotype over environments;

$\mathrm{Y}_{{ }_{\mathrm{j} .}}=$ total of $\mathrm{j}^{\text {th }}$ environment over all genotypes; and

Y.. = grand total.

Mean absolute rank difference (S1). Mean absolute rank difference' is a stability parameter proposed by Nassar and Huhn (1987). The rank of a genotype in each environment is determined first. If there are ' $n$ ' no. of environments/ locations then the possible pair-wise rank difference across the environments of the genotype would be $n \times(n-1) / 2$. Then all the rank differences were added and the average is calculated to get mean absolute rank difference of the genotype. Mean absolute rank difference estimates are all possible pair-wise rank 
differences across locations for each genotype. Genotypes with less change in rank are expected to be more stable.

AMMI stability value (ASV). The PCA scores of a genotype in the AMMI analysis are an indicator of the stability of a genotype over environments. The greater the IPCA (Interaction Principal Component Axis) scores, either negative or positive, indicated the specific adaptation of a genotype to certain environments. The more the IPCA scores approximate to zero, the more stable the genotype is over all the environments considered for the study. The mathematical function of the AMMI model following Zobel et al. (1988) is:

$\mathrm{Y}_{\mathrm{ij}}=\mu+\alpha_{i}+\beta_{j}+\sum_{k=1}^{n} \lambda_{k} \gamma_{i k} \delta_{j k}+\theta_{i j}$

where $Y_{i j}=$ mean yield of $i^{\text {th }}$ genotype in $j^{\text {th }}$ environment;

$\mu=$ grand mean;

$\alpha_{i}=$ mean deviation/effect of $i^{\text {th }}$ genotype;

$\beta_{\mathrm{j}}=$ mean deviation/effect of $\mathrm{j}^{\text {th }}$ environment;

$\lambda_{\mathrm{k}}=$ eigen value of $\mathrm{k}^{\text {th }}$ IPCA axis;

$\tilde{\mathrm{a}}_{\mathrm{ik}}=$ genotypic score of $\mathrm{i}^{\text {th }}$ genotype on $\mathrm{k}^{\text {th }}$ IPCA;

$\delta_{\mathrm{jk}}=$ environment score of $\mathrm{j}^{\text {th }}$ environment on $\mathrm{k}^{\text {th }}$ IPCA,

$\theta_{\mathrm{ij}}=$ residual of $\mathrm{G} \times \mathrm{E}$ interaction effect in $\mathrm{Y}_{\mathrm{ij}}$; and

$\mathrm{n}=$ number of IPC axes retained in the model.

A stability parameter called AMMI stability value (ASV) was estimated for each genotype using the following formula, after Purchase (1997).

$\mathrm{ASV}=\sqrt{\left(\omega \gamma_{\mathrm{i} 1}\right)^{2}+\gamma_{\mathrm{i} 2}^{2}}$

where $\omega=$ IPCA 1 SS/IPCA 2 SS (weight to IPCA 1);

$\gamma_{\mathrm{i} 1}=$ IPCA 1 score of $\mathrm{i}^{\text {th }}$ genotype; and $\gamma_{\mathrm{i} 2}=$ IPCA 2 score of $\mathrm{i}^{\text {th }}$ genotype
Estimation of stability index (STI). Stability of performance of each genotype was expressed in terms of a stability index (STI). For estimating STI, the genotypes of each maturity group were classified into stable and unstable categories on the basis of each stability parameter as discussed above and the stable genotypes were scored 1 , while unstable genotypes were scored 0 . Genotypes having $b$ values of $0.8-1.2(b \neq 1)$ were considered stable and those having $b<0.8$ or $>1.2(b \neq 1)$ were considered unstable. Nonsignificant $\mathrm{S}_{\mathrm{d}}^{2}$ of a genotype indicated stability and significant $S_{d}^{2}$ indicated unstable performance. Low (below average) value in case of CV, SF, R1, R2, W, S1 and ASV indicated stability and high (above average) value indicated unstable performance. Finally, the numerical scores of a genotype on all the 9 parameters were added to get stability index (STI) of the genotype. High value of this index indicated higher stability of yield performance of the genotypes.

\section{RESULTS}

Analysis of variance (Table 3) of yield data of the three multilocation trials of mid-early, midlate and late groups over 12 environments showed significant differences $(\mathrm{P}<0.05)$ among genotypes of each maturity group and among environments and highly significant $\mathrm{G} X \mathrm{E}$ interaction indicated differential response of the genotypes to environmental changes. Regression analysis indicated that the mean sum of squares due to environment (linear) was highly significant.

Mid-early group. Table 4 showed the stability parameters of Eberhart and Russell (1966). In the case of mid-early group, the regression coefficient (b) of the genotypes OR 1916-19, OR 1976-11, OR 2006-12 and Lalat was found to be unity $(b=0.8-1.2)$. Genotypes OR 22005, OR 2172-7 and Konark had 'b' values greater than unity $(b>1.2)$. The remaining four genotypes had b-values less than unity $(b<0.8) . S_{d}^{2}$ of the genotypes Lalat, OR 2200-5, Konark, OR 1929-4, OR 1916-19 and Bhoi were not significantly different from zero. Genotypes 
TABLE 3. Pooled analysis of variance for grain yield in rice

\begin{tabular}{llll}
\hline Source & df & MS & $F$
\end{tabular}

Pooled analysis of variance for grain yield in mid-early rice genotypes

$\begin{array}{lrlc}\text { Genotypes (G) } & 10 & 24.94 & 3.85^{\star *} \\ \text { Environments (E) } & 11 & 395.70 & 61.16^{* *} \\ \text { GxE } & 110 & 17.03 & 2.63^{* *} \\ \text { E + GxE } & 121 & & \\ \text { Environment (linear) } & 1 & 4352.71 & 296.65^{* *} \\ \text { GxE (linear) } & 10 & 28.90 & 1.97^{*} \\ \text { Pooled deviation } & 110 & 14.67 & 2.26^{* *} \\ \text { Pooled error } & 240 & 6.47 & \end{array}$

Pooled analysis of variance for grain yield in mid-late rice genotypes

$\begin{array}{lrlc}\text { Genotypes (G) } & 12 & 83.19 & 10.57^{* *} \\ \text { Environments (E) } & 11 & 900.88 & 114.50^{* *} \\ \text { GxE } & 132 & 24.19 & 3.08^{* *} \\ \text { E + GxE } & 143 & & \\ \text { Environment (linear) } & 1 & 9909.73 & 483.94^{* *} \\ \text { GxE (linear) } & 12 & 44.29 & 2.16^{*} \\ \text { Pooled deviation } & 130 & 20.48 & 2.60^{* *} \\ \text { Pooled error } & 288 & 7.87 & \end{array}$

Pooled analysis of variance for grain yield in late rice genotypes

\begin{tabular}{lrlc} 
Genotypes $(G)$ & 11 & 167.12 & $17.20^{* *}$ \\
Environments $(E)$ & 11 & 404.01 & $41.60^{* *}$ \\
$G \times E$ & 121 & 39.93 & $4.11^{* *}$ \\
E $+G \times E$ & 132 & & \\
Environment (linear) & 1 & 4444.08 & $125.30^{\star *}$ \\
GxE (linear) & 11 & 52.26 & 1.47 \\
Pooled deviation & 120 & 35.47 & $3.65^{\star *}$ \\
Pooled error & 264 & 9.71 & \\
\hline
\end{tabular}

${ }^{*}=$ significant at $5 \% ;{ }^{* *}=$ significant at $1 \%$ level

showing below average value for CV, SF, R1, R2, $\mathrm{W}$ and $\mathrm{S} 1$ (Table 5) ranked in the stable category, while those having above average value were classified as unstable. There were 7, 6, 5, 5, 6, and 6 genotypes showed stability on the basis of $\mathrm{CV}, \mathrm{SF}, \mathrm{R} 1, \mathrm{R} 2 \mathrm{~W}$ and $\mathrm{S} 1$ parameters, respectively.

The AMMI analysis of variance showed that both main effect components, i.e. genotype and location and interaction component were significant (Table 6). The main effects of genotypes and locations accounted for $8.43 \%$ and $80.86 \%$, respectively; and G'L interaction accounted for $10.71 \%$ of the total variation in
G-L data for grain yield. Table 7 indicated the AMMI 2 model IPCA 1 and IPCA 2 scores and the ASV with its ranking for the mid-early genotypes. According to ASV ranking, the most stable genotypes were OR 1976-11, Lalat, OR 1929-4, OR 2168-1, OR 2200-5 and OR 173947. This clearly indicated that genotype found to be stable on the basis of one method may not be stable on the basis of another method(s).

The rank correlation coefficient study among the nine stability parameters (Table $8 \mathrm{~b}$ ) revealed that $b$ had positive significant correlation with $\mathrm{CV}, \mathrm{SF}, \mathrm{R} 1$ and R2 and negative correlation with and $\mathrm{W}$. But $\mathrm{S}_{\mathrm{d}}^{2}$ showed negative correlation 
TABLE 4. Estimates of stability parameters ( $b$ and $S_{d}^{2}$ ) of linear regression model for grain yield $\left(\mathrm{tha}^{-1}\right)$ of rice genotypes

\begin{tabular}{|c|c|c|}
\hline Genotype & $b$ & $\mathrm{~S}_{\mathrm{d}}^{2}$ \\
\hline \multicolumn{3}{|l|}{ Mid-early } \\
\hline 1. OR $1739-47$ & $0.78(0)$ & $10.21^{*}(0)$ \\
\hline 2. OR 1916-19 & $0.94(1)$ & 6.15 \\
\hline 3. OR 1929-4 & $0.76(0)$ & 3.09 (1) \\
\hline 4. OR 1976-11 & $0.99(1)$ & $19.50^{\star \star}(0)$ \\
\hline 5. OR 2006-12 & $0.92(1)$ & $14.46^{\star \star}(0)$ \\
\hline 6. OR 2168-1 & $0.69(0)$ & $24.95^{\star *}(0)$ \\
\hline 7. OR 2172-7 & $1.23(0)$ & $9.28^{*}(0)$ \\
\hline 8. OR 2200-5 & $1.47(0)$ & $0.30 \quad(1)$ \\
\hline 9. Konark & $1.35(0)$ & $0.34 \quad(1)$ \\
\hline 10. Lalat & $1.08(1)$ & -3.95 (1) \\
\hline 11. Bhoi & $079(.0)$ & $7.16 \quad$ (1) \\
\hline Average & 1.00 & 8.20 \\
\hline \multicolumn{3}{|l|}{ Mid-late } \\
\hline 1.OR 1681-11 & $0.58(0)$ & $16.59^{* *}(0)$ \\
\hline 2.OR 1912-25 & $0.83(1)$ & 6.29 (1) \\
\hline 3.OR 1914-8 & $1.08(1)$ & $4.26 \quad(1)$ \\
\hline 4.OR 1964-8 & $1.01(1)$ & $19.69^{* *}(0)$ \\
\hline 5.OR 1967-15 & $1.17(1)$ & $7.81^{*}$ \\
\hline 6.OR 2156-15 & $0.59(0)$ & $15.68^{\star \star}(0)$ \\
\hline 7.OR 2310-12 & $0.97(1)$ & 6.00 \\
\hline 8.Pratikshya & $0.93(1)$ & $38.26^{\star \star}(0)$ \\
\hline 9.Gouri & $0.93(1)$ & $12.55^{\star *}(0)$ \\
\hline 10.Surendra & $0.93(1)$ & $19.01^{* *}(0)$ \\
\hline 11.Gajapati & $1.49(0)$ & $4.45 \quad$ (1) \\
\hline 12.Kharavela & $1.31(0)$ & $15.59^{* *}(0)$ \\
\hline 13.MTU 1001 & $1.08(1)$ & -2.26 (1) \\
\hline Average & 1.00 & 12.61 \\
\hline \multicolumn{3}{|l|}{ Late } \\
\hline 1.OR 1885-16-34 & $0.71(0)$ & $52.42^{\star \star}(0)$ \\
\hline 2.OR 1898-2-15 & $1.06(1)$ & $11.09^{*}(0)$ \\
\hline 3.OR 1898-3-16 & 1.12(1) & 3.83 (1) \\
\hline 4.OR 1901-14-32 & $0.68(0)$ & 8.11 (1) \\
\hline 5.OR 2001-1 & $0.93(1)$ & $11.46^{*}(0)$ \\
\hline 6.OR 2109-2 & $0.92(1)$ & $22.39^{\star \star}(0)$ \\
\hline 7.OR 2119-13 & $0.39(0)$ & $72.37^{\star \star}(0)$ \\
\hline 8.Savitri & $1.61(0)$ & $36.52^{* *}(0)$ \\
\hline 9.Salivahan & $1.33(0)$ & $38.50^{\star \star}(0)$ \\
\hline 10.Mahanadi & $0.84(1)$ & 0.46 (1) \\
\hline 11.Kanchan & $1.64(0)$ & $49.40^{* *}(0)$ \\
\hline 12.Jagabandhu & $0.77(0)$ & $2.47 \quad(1)$ \\
\hline Average & 1.00 & 15.60 \\
\hline
\end{tabular}

Values in brackets are the scored value, where ' 0 ' indicated unstable performance and ' 1 ' indicated stable performance. ${ }^{*}=$ significant at $5 \%,{ }^{* *}=$ significant at $1 \%$ level with $\mathrm{CV}, \mathrm{SF}, \mathrm{R} 1$ and $\mathrm{R} 2$ and positive significant correlation with W. Both S1 and ASV had no significant correlation with any other stability parameters.

So to predict stability in yield performance of a genotype all the 9 stability parameters were considered together, by scoring the genotypes in a 0-1 scale for each parameter. The STI values ranged from 0 to 8 (Table 9) in mid-early group. The genotypes OR 1739-47, OR 1929-4, OR 2168-1, OR 1916-19, OR 2006-12, Lalat and Bhoi scored high STI value (> 4.63) and were considered as stable irrespective of their yield performance. In mid-early group, the genotypes Lalat, OR 2200-5, OR 2172-7, OR 2006-12, OR 1976-11 and Konark gave above average yield (Table 9) and considered as high yielder. The two high yielding genotypes, i.e., Lalat and OR 2006-12 having high STI value indicated their wider adaptability over all environments. The genotype OR 2172-7 having high yield and STI of 0 indicated that it was highly unstable.

Mid-late group. The regression coefficient (bvalues) of the genotypes varied from 0.59 to 1.49. Nine genotypes had unity b-values. On the basis of $\mathrm{S}_{\mathrm{d}}^{2}$ values (Table 4), the genotypes OR 1912-25, OR 1914-8, OR 2310-12, Gajapati and MTU 1001 were classified as stable $\left(\mathrm{S}_{\mathrm{d}}^{2}\right.$ $0)$. The remaining 8 genotypes showed high deviation from regression $\left(S_{d}^{2}>0\right)$. On the basis of $C V, S F, R_{1}, R_{2}, W$ and $S 1$ values $8,6,7$, 6,7 and 5 genotypes respectively, were found to be stable and the rest unstable. The AMMI analysis of $\approx$ ariance showed that both main effect components, i.e., genotype and location and $\mathrm{G} \times \mathrm{E}$ interaction component were significant (Table 6). Based on ASV ranking, the genotypes OR 2310-12, OR 1681-11, OR 19148, Gouri, MTU 1001, OR 1967-15 and Surendra were found to be stable (Table 7). The rank correlation coefficient study among the nine stability parameters (Table $8 \mathrm{~b}$ ) showed that $\mathrm{b}$ had positive significant correlation with $\mathrm{CV}, \mathrm{SF}$, $\mathrm{R} 1$ and $\mathrm{W}$ and negative correlation with the rest four parameters. The $S_{d}^{2}$ showed positive significant correlation with R2 and S1. The $\mathrm{W}$ exhibited positive significant correlation with $\mathrm{b}, \mathrm{CV}, \mathrm{SF}$ and R1. But the multivariate statistics 
TABLE 5. Estimates of stability parameters $C V, S F, R 1, R 2, W$ and $S 1$ for grain yield ( $\left(\right.$ ha- ${ }^{-1}$ ) of rice genotypes

\begin{tabular}{|c|c|c|c|c|c|c|}
\hline Genotype & CV & SF & $\mathrm{R} 1$ & $\mathrm{R} 2$ & W & $\mathrm{S} 1$ \\
\hline \multicolumn{7}{|l|}{ Mid-early } \\
\hline 1. OR 1739-47 & $16.9(1)$ & $1.41(1)$ & $16.3(1)$ & $12.6(1)$ & $186.4(0)$ & $4.02(0)$ \\
\hline 2. OR 1916-19 & $18.9(1)$ & $1.97(0)$ & $23.3(0)$ & $23.3(0)$ & 127.6(1) & $2.77(1)$ \\
\hline 3. OR 1929-4 & $15.4(1)$ & $1.39(1)$ & $16.4(1)$ & $11.5(1)$ & 119.1(1) & $2.94(1)$ \\
\hline 4. OR 1976-11 & $20.4(0)$ & $1.90(0)$ & $22.8(0)$ & $22.8(0)$ & $259.7(0)$ & $4.21(0)$ \\
\hline 5. OR 2006-12 & 18.6(1) & $1.43(1)$ & 24.1(0) & $13.9(1)$ & $212.0(0)$ & $2.92(1)$ \\
\hline 6. OR 2168-1 & 19.3(1) & $1.28(1)$ & $19.5(1)$ & $9.6(1)$ & $349.9(0)$ & $3.68(0)$ \\
\hline 7. OR 2172-7 & $21.9(0)$ & $2.61(0)$ & $31.3(0)$ & $31.3(0)$ & $178.1(0)$ & $3.54(0)$ \\
\hline 8. OR 2200-5 & 24.1(0) & $2.18(0)$ & $27.8(0)$ & $27.6(0)$ & $147.7(1)$ & $4.30(0)$ \\
\hline 9. Konark & $22.9(0)$ & $2.24(0)$ & $27.6(0)$ & $25.8(0)$ & $110.2(1)$ & $3.23(1)$ \\
\hline 10. Lalat & $17.4(1)$ & $1.75(1)$ & 21.1(1) & $20.8(0)$ & $28.0(1)$ & $1.89(1)$ \\
\hline 11. Bhoi & $17.1(1)$ & $1.55(1)$ & $19.6(1)$ & $11.9(1)$ & $154.5(1)$ & $2.50(1)$ \\
\hline Average & 19.4 & 1.79 & 22.7 & 19.2 & 170.3 & 3.27 \\
\hline \multicolumn{7}{|l|}{ Mid-late } \\
\hline 1.OR 1681-11 & $17.9(1)$ & $1.60(1)$ & 24.2(1) & $322.1(0)$ & $17.6(1)$ & $3.98(0)$ \\
\hline 2.OR 1912-25 & $16.4(1)$ & $1.61(1)$ & $25.9(1)$ & $164.5(1)$ & $22.2(1)$ & $1.98(1)$ \\
\hline 3.OR 1914-8 & $23.5(0)$ & $1.67(1)$ & $32.9(0)$ & 126.6(1) & $22.5(1)$ & $2.95(1)$ \\
\hline 4.OR 1964-8 & $23.0(0)$ & $1.92(0)$ & $25.7(1)$ & $275.6(0)$ & $25.7(1)$ & $4.47(0)$ \\
\hline 5.OR 1967-15 & $26.1(0)$ & $1.85(1)$ & $32.5(0)$ & $178.9(1)$ & $27.2(0)$ & $3.77(1)$ \\
\hline 6.OR 2156-15 & $15.7(1)$ & $1.52(1)$ & $23.4(1)$ & $363.7(0)$ & $15.0(1)$ & $4.91(0)$ \\
\hline 7.OR 2310-12 & $20.6(1)$ & $1.93(0)$ & $27.7(1)$ & 139.5(1) & $27.7(0)$ & $4.82(0)$ \\
\hline 8.Pratikshya & 21.9(1) & $2.00(0)$ & $31.8(0)$ & $464.9(0)$ & $31.8(0)$ & $4.26(0)$ \\
\hline 9.Gouri & $22.4(1)$ & $2.06(0)$ & $29.0(1)$ & $207.9(1)$ & $24.9(1)$ & $4.28(0)$ \\
\hline 10.Surendra & $21.5(1)$ & $2.17(0)$ & $34.1(0)$ & $272.3(0)$ & $34.1(0)$ & $4.08(0)$ \\
\hline 11.Gajapati & $32.5(0)$ & $2.59(0)$ & $40.7(0)$ & $308.4(0)$ & $40.6(0)$ & $3.67(1)$ \\
\hline 12.Kharavela & $31.0(0)$ & $2.17(0)$ & $42.6(0)$ & $308.8(0)$ & $34.1(0)$ & $4.07(0)$ \\
\hline 13.MTU 1001 & $20.9(1)$ & $1.67(1)$ & 29.1(1) & $60.3(1)$ & $24.0(1)$ & $3.42(1)$ \\
\hline Average & 22.6 & 1.90 & 30.7 & 245.7 & 26.7 & 3.89 \\
\hline \multicolumn{7}{|l|}{ Late } \\
\hline 1.OR 1885-16-34 & $26.7(0)$ & $1.27(1)$ & $31.0(0)$ & $7.7(1)$ & $652.0(0)$ & $3.08(1)$ \\
\hline 2.OR 1898-2-15 & 20.3(1) & $1.56(1)$ & $24.5(1)$ & 15.1(1) & 209.2(1) & $3.46(1)$ \\
\hline 3.OR 1898-3-16 & $16.8(1)$ & $1.89(0)$ & $27.2(0)$ & 27.2(0) & $140.7(1)$ & $3.62(1)$ \\
\hline 4.OR 1901-14-32 & $12.7(1)$ & $1.37(1)$ & 20.3(1) & $12.5(1)$ & $217.0(1)$ & $3.47(1)$ \\
\hline 5.OR 2001-1 & 17.1(1) & $2.01(0)$ & $24.9(1)$ & $24.9(0)$ & 213.7(1) & $3.10(1)$ \\
\hline 6.OR 2109-2 & $17.7(1)$ & $1.59(1)$ & $25.2(1)$ & $20.2(0)$ & 323.3(1) & $3.18(1)$ \\
\hline 7.OR 2119-13 & $21.5(0)$ & $1.30(1)$ & $25.6(1)$ & $8.5(1)$ & $959.1(0)$ & $5.06(0)$ \\
\hline 8.Savitri & $29.5(0)$ & $2.07(0)$ & $33.2(0)$ & $30.3(0)$ & $600.5(0)$ & $4.63(0)$ \\
\hline 9.Salivahan & $28.4(0)$ & $1.94(0)$ & $28.5(0)$ & $23.0(0)$ & $522.8(0)$ & $3.90(0)$ \\
\hline 10.Mahanadi & $13.9(1)$ & $1.27(1)$ & $15.5(1)$ & 10.2(1) & $110.7(1)$ & $3.49(1)$ \\
\hline 11.Kanchan & $32.2(0)$ & $1.83(0)$ & $39.0(0)$ & $27.6(0)$ & $741.1(0)$ & $4.17(0)$ \\
\hline 12.Jagabandhu & 13.1(1) & $1.25(1)$ & $16.5(1)$ & $9.5(1)^{\prime}$ & $140.9(1)$ & $2.74(1)$ \\
\hline Average & 20.8 & 1.61 & 26.0 & 18.1 & 402.6 & 3.66 \\
\hline
\end{tabular}

Values in brackets are the scored value, where ' 0 ' indicated unstable performance and ' 1 ' indicated stable performance for each stability parameter

ASV did not show significant correlation with the univariate stability parameters.
Based on STI values (Table 9), the genotypes were identified as stable and unstable irrespective of their yield level. The genotypes 
TABLE 6. AMMI ANOVA of rice genotypes for yield

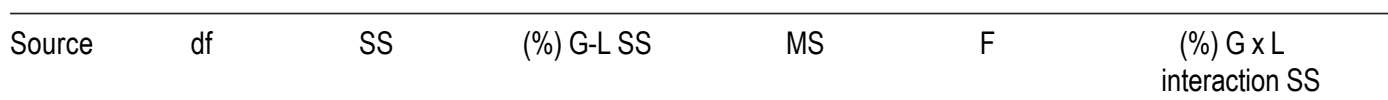

AMMI ANOVA of mid-early rice genotypes for yield

$\begin{array}{lrrrrrr}\text { Genotype (G) } & 10 & 83.449 & 8.43 & 8.35 & 3.72^{* *} & \\ \text { Location (L) } & 3 & 800.522 & 80.86 & 266.84 & 119.08^{* *} & \\ \text { G x } & 30 & 106.008 & 10.71 & 3.53 & 1.58^{*} & \\ \text { IPCA1 } & 12 & 65.185 & 6.58 & 5.43 & 2.42^{* *} & 61.49 \\ \text { IPCA2 } & 10 & 26.503 & 2.68 & 2.65 & 1.18 & 25.00 \\ \text { Residual } & 8 & 14.320 & 1.45 & 1.79 & 0.80 & 13.51 \\ \text { Error } & 240 & 537.792 & & 2.24 & & \end{array}$

AMMI ANOVA of mid-late rice genotypes for yield

\begin{tabular}{|c|c|c|c|c|c|c|}
\hline Source & df & SS & (\%) G-L SS & MS & $\mathrm{F}$ & $\begin{array}{c}(\%) G \times L \\
\text { interaction SS }\end{array}$ \\
\hline Genotype (G) & 12 & 332.734 & 17.71 & 27.73 & $9.81^{* *}$ & \\
\hline Location (L) & 3 & 1286.190 & 68.45 & 428.73 & $151.62^{* *}$ & \\
\hline $\mathrm{G} \times \mathrm{L}$ & 36 & 260.067 & 13.84 & 7.22 & $2.56^{* *}$ & \\
\hline IPCA 1 & 14 & 107.879 & 5.74 & $7.71^{* *}$ & $2.73^{*}$ & 41.48 \\
\hline IPCA2 & 12 & 89.167 & 4.75 & $7.43^{* *}$ & $2.63^{*}$ & 34.29 \\
\hline Residual & 10 & 63.069 & 3.36 & 6.30 & $2.24^{*}$ & 24.23 \\
\hline Error & 288 & 814.378 & & 2.83 & & \\
\hline \multicolumn{7}{|c|}{ AMMI ANOVA of late rice genotypes for yield } \\
\hline Source & $d f$ & SS & (\%) G-L SS & MS & $\mathrm{F}$ & $\begin{array}{c}(\%) G \times L \\
\text { interaction SS }\end{array}$ \\
\hline Genotype (G) & 11 & 612.828 & 44.54 & 55.71 & $17.21^{* *}$ & \\
\hline Location $(\mathrm{L})$ & 3 & 221.052 & 16.07 & 73.68 & $22.76^{* *}$ & \\
\hline $\mathrm{G} \times \mathrm{L}$ & 33 & 541.923 & 39.39 & 16.42 & $5.07^{* *}$ & \\
\hline IPCA1 & 13 & 432.662 & 31.45 & 33.28 & $10.28^{* *}$ & 79.84 \\
\hline IPCA2 & 11 & 96.934 & 7.04 & 8.81 & $2.72^{* \star}$ & 17.89 \\
\hline Residual & 9 & 12.327 & 0.90 & 1.37 & 0.42 & 2.27 \\
\hline Error & 264 & 854.858 & & 3.24 & & \\
\hline
\end{tabular}

${ }^{*}=$ significant at $5 \%,{ }^{* *}=$ significant at $1 \%$ level

OR 1912-25, OR 2310-12 and MTU 1001 with high yield and high STI value were considered as widely adapted genotypes and they were agronomically superior.

Late group. The regression coefficient (bvalues) of the late group genotypes ranged from 0.39 to 1.64 (Table 4 ). Five genotypes showed unit regression $(b=0.8-1.2)$. Based on $S_{d}^{2}$ values, four genotypes were found to be stable and rest eight were unstable. There were 7, 7,
7, 6, 7 and 8 genotypes had below average values for the parameters $\mathrm{CV}, \mathrm{SF}, \mathrm{R}_{1}, \mathrm{R}_{2}, \mathrm{~W}$ and $\mathrm{S} 1$ (Table 5), respectively and were considered as stable (Table 5). The AMMI analysis of variance showed that genotype $(\mathrm{G})$, location $(\mathrm{L})$ and $\mathrm{G}^{\prime} \mathrm{L}$ interaction components were significant at $1 \%$ level. The multivariate stability statistics ASV indicated that the genotypes Mahanadi, OR 1898-3-16, Jagabandhu, OR 1898-2-15, OR 2109-2 and OR 1885-16-34 were stable. The rank and rank correlation coefficient study 
TABLE 7. The IPCA1 and IPCA2 scores along with AMMI stability value (ASV) for grain yield ( tha $^{-1}$ ) of rice genotypes

\begin{tabular}{|c|c|c|c|}
\hline Genotype & A Score1 & IPCAScore2 & ASV \\
\hline \multicolumn{4}{|l|}{ Mid-early } \\
\hline 1. OR $1739-47$ & -0.76 & -0.40 & $1.26(1)$ \\
\hline 2. OR 1916-19 & -1.33 & -0.07 & $2.08(0)$ \\
\hline 3. OR 1929-4 & 0.38 & -0.12 & $0.61(1)$ \\
\hline 4. OR 1976-11 & 0.22 & 0.15 & $0.38(1)$ \\
\hline 5. OR 2006-12 & 1.49 & -0.67 & $2.44(0)$ \\
\hline 6. OR 2168-1 & 0.59 & -0.15 & $0.93(1)$ \\
\hline 7. OR 2172-7 & -0.96 & 1.46 & $2.10(0)$ \\
\hline 8. OR 2200-5 & 0.64 & 0.72 & $1.23(1)$ \\
\hline 9. Konark & 0.79 & 0.61 & $1.38(0)$ \\
\hline 10. Lalat & -0.06 & -0.39 & $0.40(1)$ \\
\hline 11. Bhoi & -1.00 & -1.14 & $1.95(0)$ \\
\hline \multicolumn{4}{|l|}{ Mid-late } \\
\hline 1.OR 1681-11 & -0.41 & 0.40 & $0.60(1)$ \\
\hline 2.OR 1912-25 & 1.43 & 0.01 & $1.57(0)$ \\
\hline 3.OR 1914-8 & -0.51 & 0.33 & $0.65(1)$ \\
\hline 4.OR 1964-8 & 0.54 & -1.44 & $1.55(0)$ \\
\hline 5.OR 1967-15 & -0.49 & 0.77 & $0.94(1)$ \\
\hline 6.OR 2156-15 & -0.25 & 1.28 & $1.31(0)$ \\
\hline 7.OR 2310-12 & -0.05 & 0.56 & $0.56(1)$ \\
\hline 8.Pratikshya & 2.34 & 0.47 & $2.61(0)$ \\
\hline 9.Gouri & -0.67 & 0.51 & $0.90(1)$ \\
\hline 10.Surendra & 0.03 & -1.05 & $1.05(1)$ \\
\hline 11.Gajapati & -0.36 & -1.20 & $1.26(0)$ \\
\hline 12.Kharavela & -0.89 & -1.14 & $1.50(0)$ \\
\hline 13.MTU 1001 & -0.70 & 0.49 & $0.92(1)$ \\
\hline \multicolumn{4}{|l|}{ Late } \\
\hline 1.OR 1885-16-34 & -0.35 & -2.21 & $2.33(1)$ \\
\hline 2.OR 1898-2-15 & -0.38 & -0.36 & $0.88(1)$ \\
\hline 3.OR 1898-3-16 & 0.33 & -0.29 & $0.75(1)$ \\
\hline 4.OR 1901-14-32 & 1.15 & 0.08 & $2.43(0)$ \\
\hline 5.OR 2001-1 & 1.20 & 0.41 & $2.56(0)$ \\
\hline 6.OR 2109-2 & 0.44 & 0.79 & $1.22(1)$ \\
\hline 7.OR 2119-13 & 3.06 & 0.04 & $6.47(0)$ \\
\hline 8.Savitri & -1.35 & 0.74 & $2.94(0)$ \\
\hline 9.Salivahan & -1.36 & 1.66 & $3.32(0)$ \\
\hline 10.Mahanadi & -0.34 & 0.21 & $0.74(1)$ \\
\hline 11.Kanchan & -2.05 & -0.64 & $4.37(0)$ \\
\hline 12.Jagabandhu & -0.36 & -0.42 & $0.87(1)$ \\
\hline
\end{tabular}

Values in brackets are the scored value, where ' 0 ' indicated unstable performance and ' 1 ' indicated stable performance for the stability parameter ASV.

among the nine stability parameters (Table 8a and $8 \mathrm{~b}$ ) showed that $\mathrm{b}$ had positive significant correlation with $\mathrm{CV}, \mathrm{SF}$ and $\mathrm{R} 2$ and limited correspondence with the rest five parameters.
The Wricke's procedure of stability statistics exhibited positive significant correlation with $\mathrm{S}_{\mathrm{d}}^{2}, \mathrm{CV}$, and R1. The multivariate statistics ASV showed significant positive correlation with $\mathrm{S}_{\mathrm{d}}^{2}, \mathrm{CV}, \mathrm{R} 1$ and $\mathrm{W}$. But $\mathrm{S} 1$ did not show significant correlation with any other stability parameter.

Stability index in late group (Table 9) revealed that genotypes OR 1898-2-15, OR 1898-3-16, OR 1901-14-32, OR 2109-2, OR 2001-1, Mahanadi and Jagabandhu with above average STI value $(>4.75)$ had reflected consistency in their yield performance. High mean yield along with high STI value for the genotypes OR 1898-3-16, OR 1901-14-32, OR 2109-2, OR 2001-1, Mahanadi and Jagabandhu indicated their general adaptation. The high yielding genotype Mahanadi was found to be stable for each of the 9 parameters and considered as unique as compared to other high yielding genotypes.

\section{DISCUSSION}

The present study clearly showed that genotypes of mid-early, mid-late and late group differed greatly in their yield stability for each of the univariate and multivariate stability parameters (Tables 4, 5 and 7.). According to authors knowledge integration of both the univariate and multivariate methods to assess adaptability is very scanty. Mahapatra (1993) estimated adaptability of 12 rice varieties by integrating eight univariate methods along with mean yield. In mid-early group the number of stable genotypes is highest (7) according to $\mathrm{CV}$ and least (4) on the basis of $b$ value. In the mid-late group, the number of stable genotypes is highest (9) according to b value and lowest (5) on the basis of $\mathrm{S}_{\mathrm{d}}^{2}$ and $\mathrm{S} 1 \mathrm{value}$. In the late group, highest (8) number of stable genotypes is observed according to $\mathrm{S} 1$ parameter and least (4) on the basis of $S_{d}^{2}$ value.

The rank correlation coefficient in the present investigation indicated that the stability statistics showed variation in their degree of correlation and were not the same for all the maturity groups. In the mid-early group W showed positive significant correlation with $S_{d}^{2}$ but not with other stability statistics. However, 
TABLE 8a. Ranking order of the nine stability parameters in different maturity groups of rice.

\begin{tabular}{|c|c|c|c|c|c|c|c|c|}
\hline b & $\mathrm{S}_{\mathrm{d}}^{2}$ & CV & SF & $\mathrm{R} 1$ & $\mathrm{R} 2$ & W & $\mathrm{S} 1$ & ASV \\
\hline \multicolumn{9}{|c|}{ Mid-early } \\
\hline 3 & 8 & 2 & 3 & 1 & 4 & 8 & 9 & 6 \\
\hline 6 & 5 & 6 & 8 & 7 & 8 & 4 & 3 & 9 \\
\hline 2 & 4 & 1 & 2 & 2 & 2 & 3 & 5 & 3 \\
\hline 7 & 10 & 8 & 7 & 6 & 7 & 10 & 10 & 1 \\
\hline 5 & 9 & 5 & 4 & 8 & 5 & 9 & 4 & 11 \\
\hline 1 & 11 & 7 & 1 & 3 & 1 & 11 & 8 & 4 \\
\hline 9 & 7 & 9 & 11 & 11 & 11 & 7 & 7 & 10 \\
\hline 11 & 2 & 11 & 9 & 10 & 10 & 5 & 11 & \\
\hline 10 & 3 & 10 & 10 & 9 & 9 & 2 & 6 & \\
\hline 8 & 1 & 4 & 6 & 5 & 6 & 1 & 1 & 2 \\
\hline 4 & 6 & 3 & 5 & 4 & 3 & 6 & 2 & 8 \\
\hline
\end{tabular}

\section{Mid-late}

\begin{tabular}{|c|c|c|c|c|c|c|c|c|}
\hline 1 & 10 & 3 & 2 & 2 & 11 & 2 & 6 & 2 \\
\hline 3 & 5 & 2 & 3 & 4 & 4 & 3 & 1 & 12 \\
\hline 10 & 2 & 10 & 5 & 10 & 2 & 4 & 2 & 3 \\
\hline 8 & 12 & 9 & 7 & 3 & 8 & 7 & 11 & 11 \\
\hline 11 & 6 & 11 & 6 & 9 & 5 & 8 & 5 & 6 \\
\hline 2 & 9 & 1 & 1 & 1 & 12 & 1 & 13 & 9 \\
\hline 7 & 4 & 4 & 8 & 5 & 3 & 9 & 12 & 1 \\
\hline 4 & 13 & 7 & 9 & 8 & 13 & 10 & 9 & 13 \\
\hline 5 & 7 & 8 & 10 & 6 & 6 & 6 & 10 & 4 \\
\hline 6 & 11 & 6 & 11 & 11 & 7 & 11 & 8 & 7 \\
\hline 13 & 3 & 13 & 13 & 12 & 9 & 13 & 4 & 8 \\
\hline 12 & 8 & 12 & 12 & 13 & 10 & 12 & 7 & 10 \\
\hline 9 & 1 & 5 & 4 & 7 & 1 & 5 & 3 & 5 \\
\hline \multicolumn{9}{|c|}{ Late } \\
\hline 3 & 11 & 9 & 3 & 10 & 1 & 10 & 2 & 6 \\
\hline 8 & 5 & 7 & 6 & 4 & 6 & 4 & 5 & 4 \\
\hline 9 & 3 & 4 & 9 & 8 & 10 & 2 & 8 & 2 \\
\hline 2 & 4 & 1 & 5 & 3 & 5 & 6 & 6 & 7 \\
\hline 7 & 6 & 5 & 11 & 5 & 9 & 5 & 3 & 8 \\
\hline 6 & 7 & 6 & 7 & 6 & 7 & 7 & 4 & 5 \\
\hline 1 & 12 & 8 & 4 & 7 & 2 & 12 & 12 & 12 \\
\hline 11 & 8 & 11 & 12 & 11 & 12 & 9 & 11 & 9 \\
\hline 10 & 9 & 10 & 10 & 9 & 8 & 8 & 9 & 10 \\
\hline 5 & 1 & 3 & 2 & 1 & 4 & 1 & 7 & 1 \\
\hline 12 & 10 & 12 & 8 & 12 & 11 & 11 & 10 & 11 \\
\hline 4 & 2 & 2 & 1 & 2 & 3 & 3 & 1 & 3 \\
\hline
\end{tabular}

b = regression coefficient, $\mathbf{S}_{\mathbf{d}}^{\mathbf{2}}=$ deviation from regression, $\mathrm{CV}=$ coefficient of variation, $\mathrm{SF}=$ stability factor, $\mathrm{R} 1$ = range 1,

$\mathrm{R} 2$ = range $2, \mathrm{~W}=$ Wricke's ecovalence, $\mathrm{S} 1$ = mean absolute rank difference, $\mathrm{ASV}=\mathrm{AMMI}$ stability value

$\mathrm{S} 1$ and ASV did not have positive significant correlation with other stability parameters.

In the mid-late group, $\mathrm{W}$ showed a positive significant correlation with $\mathrm{b}, \mathrm{CV}, \mathrm{SF}$ and $\mathrm{R} 1$;
S1 showed positive significant correlation only with $\mathrm{S}_{\mathrm{d}}^{2}$ and $\mathrm{ASV}$ had at all no significant correlation with any other stability parameters. In late group, the highest positive significant 
TABLE 8b. Rank correlation among the nine stability parameters in different maturity groups of rice

\begin{tabular}{|c|c|c|c|c|c|c|c|c|c|}
\hline \multicolumn{10}{|c|}{ Mid-early } \\
\hline & $b$ & $\mathrm{~S}_{\mathrm{d}}^{2}$ & CV & SF & $\mathrm{R} 1$ & $\mathrm{R} 2$ & W & S1 & ASV \\
\hline b & & -.565 & $.745^{\star}$ & $.918^{\star *}$ & $.845^{\star *}$ & $.927^{\star *}$ & -.418 & .155 & .100 \\
\hline $\mathrm{S}_{\mathrm{d}}^{2}$ & & & -.063 & -.418 & -.245 & -.382 & $.945^{\star *}$ & .336 & .118 \\
\hline $\mathrm{CV}$ & & & & $.727^{\star}$ & $.818^{*}$ & $.745^{\star}$ & .081 & .500 & .100 \\
\hline SF & & & & & $.863^{\star *}$ & $.963^{\star *}$ & -.354 & .100 & .290 \\
\hline R1 & & & & & & $.881^{* *}$ & -.136 & .127 & .454 \\
\hline R2 & & & & & & & -.281 & .227 & .281 \\
\hline S1 & & & & & & & & .509 & .081 \\
\hline ASV & & & & & & & & & -.263 \\
\hline \multicolumn{10}{|c|}{ Mid-late } \\
\hline b & & -.478 & $.862^{\star *}$ & $.577^{*}$ & $.769^{\star \star}$ & -.329 & $.643^{*}$ & -.319 & -.038 \\
\hline $\mathrm{S}_{\mathrm{d}}^{2}$ & & & -.137 & .087 & -.242 & $.764^{* *}$ & .089 & $.577^{\star}$ & .467 \\
\hline CV & & & & $.709^{*}$ & $.775^{\star \star}$ & -.011 & $.687^{*}$ & -.220 & .082 \\
\hline SF & & & & & $.758^{\star \star}$ & .132 & $.934^{\star *}$ & .115 & .143 \\
\hline R1 & & & & & & -.115 & $.780^{* *}$ & -.384 & .066 \\
\hline R2 & & & & & & & .137 & .462 & .478 \\
\hline S1 & & & & & & & & .071 & .209 \\
\hline ASV & & & & & & & & & .016 \\
\hline \multicolumn{10}{|l|}{ Late } \\
\hline b & & .056 & $.566^{\star}$ & $.741^{*}$ & .552 & $.888^{* *}$ & .013 & .350 & .147 \\
\hline $\mathrm{S}_{\mathrm{d}}^{2}$ & & & $.811^{\star *}$ & .252 & $.762^{\star *}$ & -.007 & $.958^{* *}$ & .392 & $.832^{* *}$ \\
\hline $\mathrm{CV}$ & & & & .476 & $.874^{\star *}$ & .378 & $.755^{\star *}$ & .510 & $.671^{*}$ \\
\hline SF & & & & & $.566^{*}$ & $.881^{\star *}$ & .196 & .398 & .420 \\
\hline R1 & & & & & & .483 & $.727^{*}$ & .482 & $.615^{*}$ \\
\hline R2 & & & & & & & .007 & .413 & .216 \\
\hline S1 & & & & & & & & .440 & $.881^{* *}$ \\
\hline ASV & & & & & & & & & .559 \\
\hline
\end{tabular}

$\mathrm{b}=$ regression coefficient, $\mathbf{S}_{\mathbf{d}}^{\mathbf{2}}=$ deviation from regression, $\mathrm{CV}=$ coefficient of variation, $\mathrm{SF}=$ stability factor, $\mathrm{R} 1$ = range 1 , $\mathrm{R} 2$ = range $2, \mathrm{~W}=$ Wricke's ecovalence, $\mathrm{S} 1=$ Mmean absolute rank difference, $\mathrm{ASV}=\mathrm{AMMI}$ stability value

correlation was observed between $\mathrm{W}$ and $\mathrm{S}_{\mathrm{d}}^{2}$ and ASV showed significant positive correlation with $\mathrm{S}_{\mathrm{d}}^{2}, \mathrm{CV}, \mathrm{R} 2$ and $\mathrm{W}$. Therefore, we integrate different stability parameters to predict genotypic adaptation in rice.

According to STI estimate seven genotype from each maturity group are found to be stable. The high yielding genotypes MTU 1001 of midlate group and Mahanadi of late group are stable for each of the stability parameters and it may be supposed due to the involvement of multiple genes in controlling sensitivity to environmental changes. The present study suggests that integration of several approaches of stability analysis is better than the use of a single approach in predicting genotypic adaptation.

\section{CONCLUSION}

Integration of univariate and multivariate approaches in the present study indicate that the mid-early group genotypes Lalat and OR 200612 , the mid-late group genotypes OR 1912-25, OR 2310-12 and MTU 1001 and the late group 
TABLE 9. Estimates of grain yield $\left(t a^{-1}\right)$ and $S T I$ value of rice genotypes

\begin{tabular}{lccc}
\hline Genotype & $\begin{array}{c}\text { Mean } \\
\text { yield }\left(\mathrm{tha}^{-1}\right)\end{array}$ & $\begin{array}{c}\text { Yield } \\
\text { rank }\end{array}$ & $\begin{array}{c}\text { Stability } \\
\text { index (STI) }\end{array}$ \\
\hline
\end{tabular}

Mid-early group

1. OR $1739-47$

2. OR $1916-19$

3.604

3. OR 1929-4

3.495

4. OR $1976-11$

3.524

5. OR 2006-12

3.763

6. OR 2168-1

3.772

7. OR $2172-7$

3.507

8. OR 2200-5

3.782

9. Konark

3.787

10. Lalat

3.687

11. Bhoi

3.842

Average

3.655

Mid-late group

1. OR 1681-11

2. OR $1912-25$

4.130

3. OR $1914-8$

4. OR 1964-8

5. OR $1967-15$

6. OR $2156-15$

7. OR $2310-12$

8. Pratikshya

9. Gouri

10. Surendra

11. Gajapati

12. Kharavela

13. MTU 1001

Average

4.745

4.084

4.241

4.011

4.305

4.266

4.605

3.960

4.271

3.961

3.827

4.408

4.216

Late group

1. OR 1885-16-34 3.215

2. OR 1898-2-15 3.702

3. OR 1898-3-16 4.394

4. OR 1901-14-32 4.445

5. OR 2001-1 4.072

6. OR 2109-2 4.299

7. OR 2119-13 4.146

8. Savitri $\quad 3.859$

9. Salivahan $\quad 3.587$

10. Mahanadi $\quad 4.150$

11. Kanchan $\quad 3.726$

12. Jagabandhu $\quad 4.265$

Average

3.988 genotypes OR 1898-3-16, OR 1901-14-32, OR 2109-2, OR 2001-1, Mahanadi and Jagabandhu have wide adaptability.

\section{ACKNOWLEDGEMENT}

The authors acknowledge the Department of Plant breeding and Genetics, OUAT, Bhubaneswar for providing facilities to conduct the research work.

\section{REFERENCES}

Akcura, M., Kaya, Y. and Taner, S. 2005 Genotype-environment interaction and phenotypic stability analysis for grain yield of durum wheat in the Central Anatolian region. Turky Journal of Agriulture 29: 369-375.

Asenjo, C.A., Bezus, R. and.Acciaresi, H.A. 2003. Genotype $x$ environment interaction in rice (Oryza sativa L.) in temperate regions using the Joint Regression Analysis and AMMJ methods. Cereal Research of Communication 32:97-104.

Becker, H.C. and Leon, J. 1988. Stability analysis in plant breeding. Plant breeding 101:1-23.

Bose, L.K., Mohanty, A., Kar, M. K. and Nagaraju, M. (2004). Stability analysis of grain yield in rice under different agronomic practices. Crop Improvement 6:26-29.

Chandrasiri, G.W.J., Abeysiriwardena, D.S., Pieris, B.L. and Jayathilake, H.M.C.K. 2002. Comparative evaluation of different statistical techniques on testing adaptability of rice varieties in varied environments. Annals of the Sri Lanka Department of Agriculture 4: 1-13.

Chaudhari, L.B.,. Singh, R and. Rai, R.S.1977. Genotype $\mathrm{x}$ environment interactions in finger millet. Indian Journal of Agriultural Science 47:237-240.

Crossa, J. 1990. Statistical analysis of multilocation trials. Advances in Agronomy 44:55-85. 
Das, S., Mishra, R.C. and Sinha, S.K. 2008. Variation in seedling growth inhibition due to maleic hydrazide treatment of rice $(O$. sativa) and ragi (E coracana) genotypes and its relationship with yield and adaptability. Journal of Crop Science and Biotechnology 11(3):215-222.

Eberhart, S.A. and Russell, W.A. 1966. Stability parameters for comparing varieties. Crop Science 6:36-40.

Francis, P.V., Kanakmany, M.T., Radhakrishnan, V.V. and Jaikumaran, U. 2005. Genotype x environment interaction in rice. Oryza 42: 174-178.

Francis, T.R. and Kannenberg, L.W. 1978. Yield stability studies in short season-maize. I. A descriptive method for grouping genotypes. Canadian Journal of Plant Science 58: 1029-1034.

Hohls, T. 1995 .Analysis of genotypeenvironment interactions. South African Journal of Science 91:121-124.

Langer, I., Frey, K.J. and Bailey, T. 1979. Associations among productivity, production response and stability indices in oat varieties. Euphytica 28:17-24.

Lewis, L.B. 1954. Gene-environment interaction. Heredity 8: 333-356.

Lin, C.S., Binns, M.R. and Lefkovitch, L.P. 1986. Stability analysis: Where dowe stand? Crop Science 26: 894-900.

Mahalingam, L., Mahendran, S. , Chandra, R. and Atlin, G. 2006. AMMI analysis for stability of grain yield in rice ( $O$. sativa $\mathrm{L}$.) International Journal of Botany 2:104106.

Mahapatra, K.C. 1993. Relative usefulness of stability parameters in assessing adaptability in rice. Indian Journal of Genetics and Plant Breeding 53:435-441.
Mohapatra, K.C. and Das, S. 1998. Approaches to analysis of genotypic adaptation in rice. Indian Journal of Genetics and Plant Breeding 58(3):297-306.

Nanita Devi, H., Singh, N.B., Singh, M.R.K. and Sharma, P.R. 2006. Stability analysis of selected rice genotypes at varying spacing and sowing dates under rainfed lowland condition in Manipur Valley. Oryza 43:2024.

Nassar, R. and Huhn, M.1987. Studies on estimation of phenotypic stability: Test of significance for non-parametric measures $\mathrm{c}$. stability. Biometrics 43:45-53.

Purchase, J.L. 1997. Parametric analysis to describe genotype $\mathrm{x}$ environment interaction and yield stability in winter wheat. Parametric analysis to describe genotype $\mathrm{x}$ environment interaction and yield stability in winter wheat. Ph. D. Thesis. Department of Agronomy, Faculty of Agriculture of the University of the Free State, Bloemfontein, South Africa.

Purchase, J.L., Hatting, H, and VanDevendra, C.S. 2000. Genotype $x$ environment interaction of winter wheat (Triticum aestivum L.) in South Africa: Stability analysis of yield performance. Sout Africa Journal of Plant soil 17:101-107.

Romagosa, I. and Fox, P.N. 1993. Genotype x Environment interaction and adaptation. In Plant breeding: principles and prospects, edited by Hayward, Bosemark and Romagosa, Chapman and Hall, London, UK. pp. 373-390.

Wricke, G. 1962. Uber cine methode zur enfassung der okologishaen streubreite in feldverzuchen. Z. Pilanzenzuchig 47:92-96.

Zobel, R.W., Madison, J.W. and Gouch, H.G. 1988. Statistical analysis of a yield trial. Agronomy Journal 80:388-393. 